\title{
Knowledge and attitude towards pregnancy-related issues of Zika virus infection among general practitioners in Indonesia
}

Harapan Harapan ${ }^{1,2,3,4^{*}}$ (D, Yogambigai Rajamoorthy ${ }^{5}$, Prattama S. Utomo ${ }^{6}$, Samsul Anwar $^{7}$, Abdul M. Setiawan ${ }^{8}$, Alma Alleta ${ }^{1,9}$, Alfredo Bambang ${ }^{10}$, Muhammad R. Ramadana', Ikram Ikram¹, Nur Wahyuniati ${ }^{1}$, Reza Maulana ${ }^{1}$, Ichsan Ichsan 1,2,3, Rosaria Indah 11,12, Abram L. Wagner ${ }^{13}$, Ulrich Kuch ${ }^{14}$, David A. Groneberg ${ }^{14}$, Alfonso J. Rodríguez-Morales ${ }^{15,16}$, Mohd Andalas ${ }^{1,17}$, Ruth Müller ${ }^{14,18}$, Mudatsir Mudatsir ${ }^{1,2,3^{*}}$ and Allison Imrie ${ }^{4}$

\begin{abstract}
Background: The aim of this study was to assess the knowledge and attitudes towards pregnancy-related issues of Zika virus (ZIKV) infection among general practitioners (GPs), a frontline healthcare worker group, in Indonesia.

Methods: A cross-sectional, online survey assessing knowledge and attitudes towards ZIKV infection on multiple-item scales was sent to GPs in the Sumatra and Java islands of Indonesia. The associations between independent factors and either knowledge or attitude were assessed with logistic regressions. The correlation and association between knowledge and attitude were estimated.

Results: We included 457 (53.7\%) out of 850 responses in the analysis. Among these, 304 (66.5\%) and 111 (24.2\%) respondents had a good knowledge and attitude, respectively. No demographic, workplace, professional development, or experiential characteristics related to ZIKV infection were associated with knowledge. In the multivariate analysis, only contact experience was associated with attitude. There was a significant, positive correlation between knowledge and attitude scores.

Conclusions: Although knowledge of pregnancy-related complications of ZIKV infection is relatively high among GPS in Indonesia, more than 75\% of them had a poor attitude towards pregnancy-related issues of Zika. Strategies for enhancing the capacity of GPs to develop positive attitudes and respond to ZIKV infection are needed.
\end{abstract}

Keywords: Zika virus, Knowledge, Attitude, General practitioner, Healthcare worker

\section{Background}

Zika virus (ZIKV) is transmitted by Aedes aegypti and Aedes albopictus mosquitoes. Infection by ZIKV most often results in mild symptoms such as fever, maculopapular rash, arthralgia, cephalgia and conjunctivitis [1]. However, the infection may cause severe complications including neurological sequelae and Guillain-Barré syndrome [2]. In addition, ZIKV-related congenital microcephaly, ventriculomegaly and intracranial calcification

\footnotetext{
* Correspondence: harapan@unsyiah.ac.id; mudatsir@unsyiah.ac.id

${ }^{1}$ Medical Research Unit, School of Medicine, Universitas Syiah Kuala, Banda

Aceh, Indonesia

Full list of author information is available at the end of the article
}

have been identified in infants born to ZIKV-positive mothers [3]. There is a strong association between congenital ZIKV infection and microcephaly; one study estimates the odds of microcephaly to be 73.1 times higher among those with ZIKV infection [4]. Multiple outbreaks of microcephaly-associated with Zika cases have been reported since reemerge [5-9]. In Brazil for example, during two Zika outbreaks in 2015 and 2016, more than 1.6 million cases were reported and during this period, 1950 cases of ZIKV infection-related microcephaly were confirmed [9]. This devastating complication was one factor that led the WHO to declare ZIKV infection as a Public Health Emergency of 
International Concern (PHEIC) and as an ongoing challenge in 2016 [10]. Microcephaly associated with ZIKV infection has been also reported in Asian countries [11-13].

ZIKV was first found in Africa over 70 years ago when it was identified in a monkey in 1947 [14] and in humans in 1954 [15]. After local outbreaks in various Pacific Islands [16], the virus reached the Americas (Brazil) in 2015 [17], and has since continued to spread and has been reported in 86 countries in the Americas, Africa, and Southeast Asia [18]. Globally, it is predicted that over 2.17 billion people live in areas that are environmentally suitable for ZIKV transmission, and 1.42 billion of them live in Asia [19]. Asia is susceptible to epidemic ZIKV transmission because of widespread distribution of the mosquito vectors for ZIKV, the large amount of travel to and from Zika-affected areas, conducive conditions for ZIKV transmission, and limited health resources [20-23].

A recent modeling study ranked Indonesia as the third country most at risk for ZIKV exposure due to the monthly volume of airline travelers [21]. Indonesia has not yet had a Zika outbreak, but there is evidence of ZIKV transmission in the country. Studies using serum samples from 1978 and 1983 found evidence of antiZIKV antibodies in Central Java and Lombok [24, 25]. In 2014, 9.1\% of serum samples from children 1-4 years old were ZIKV seropositive [26]. In 2013 and 2014, two travelers visiting Indonesia acquired ZIKV infection and were diagnosed after returning to Australia [27, 28]. In 2015 , an individual with no history of traveling abroad was diagnosed with Zika [29]. Zika cases may be underestimated in Indonesia for three major reasons: (1) the clinical presentation of Zika and dengue is similar; (2) the availability of Zika diagnostic tests is limited in Indonesia; and (3) Zika reports are based on passive case-based surveillance [30, 31].

In order to mitigate Zika complications, in particular pregnancy-related complications, it is important to diagnose the disease in its early stages and implement prevention programmes. Assessment of the knowledge about ZIKV infection among healthcare workers (HCWs) can identify problems that HCWs may face in reaching this diagnosis. Zika-related knowledge is important since knowledge gaps may lead to attitudes and practices that hamper ZIKV infection diagnosis, management, and risk reduction [32].

Studies related to knowledge and attitude towards ZIKV infection have been conducted in various community groups. At least 21 studies related to knowledge of ZIKV infection have been conducted [1,33-52], in the general population [33-37] or specific groups such as reproductive-age women [38, 39], pregnant women [40-43], construction workers [44], and medical [1, 39, $45-49,52]$ and non-medical university students [33, 52]. Five of these studies were conducted among HCWs $[1,39$,
$45,50,51]$. Ten studies related to attitude towards ZIKV infection have been conducted [34, 35, 37, 41, 48, 52-55], but only one of these among HCWs [56]. These figures indicate that information about knowledge and attitude towards ZIKV infection among HCWs is limited. Given the fact that HCWs have critical roles in the prevention and management of Zika disease, studies to fill this gap in the literature are required.

In Indonesia, general practitioners (GPs) are the frontline HCWs who are responsible for the early diagnosis, treatment, and prevention of diseases including ZIKV infection. Thus, GPs in Indonesia should have some knowledge to treat ZIKV infection because it has the general manifestation of fever, which is included in the competency list of general medical practice [57]. In addition, the symptoms of ZIKV infection are similar to those of other mosquito-borne infections such as dengue fever or chikungunya fever [58]. It is important for GPs to recognize symptoms of ZIKV infection in order to detect or prevent complications. Most Zika prevention measures, including the strategic responses set out by the WHO, are also within the GPs' competency list. These circumstances indicate that GPs play a pivotal role in the early detection and prevention of ZIKV infection in Indonesia.

Previously, our group conducted a project to assess the knowledge and attitude towards ZIKV infection among doctors in Aceh province of Indonesia [51, 56]. Both specialist doctors and GPs were included, and multiple stratified analyses indicated that specialists had a lower knowledge and a less positive attitude compared to GPs. To generalize these results in the national context, an expanded survey that included other regions of Indonesia was conducted. As GPs are the frontline HCWs in Indonesia, and because one of the most important issues related to ZIKV infection is congenital microcephaly, the survey sampled GPs and focused on the pregnancy-related issues of ZIKV infection. Thus, this study sought to provide a comprehensive picture of the knowledge and attitude towards pregnancy-related issues of ZIKV infection among GPs in Indonesia.

\section{Methods}

\section{Study design and survey instrument}

Following our previous survey of HCWs in Aceh province $[51,56]$, another survey, from October to December 2016, on GPs' knowledge and attitude towards pregnancy-related issues of ZIKV infection was conducted in a larger area (encompassing Sumatra and Java islands, which together are inhabited by about 200 million individuals, or approximately $80 \%$ of the entire population of Indonesia). This study was cross-sectional and used an online survey which was estimated to take around five to ten minutes to complete. To assess knowledge and 
attitude, a questionnaire was developed based on existing facts from the United States Centers for Disease Control and Prevention (CDC) [17]. The questions were translated into Bahasa Indonesia (national language), and a panel consisting of two medical microbiologists was appointed to evaluate the validity of the questionnaire content. Prior to the actual study, the reliability of the questions was tested in a pilot study, and the data from this pilot study were excluded from the final analysis. The Cronbach's alpha score was 0.78 and 0.70 for knowledge and attitude domain, respectively, indicating good internal consistency of the items in the scale. The design, setting, analyses and reporting of this study adhered to the STROBE guidelines for cross-sectional studies in epidemiology (see Additional file 1 for the detailed checklist of STROBE criteria [59]).

\section{The survey and data collection}

The Survey Monkey web portal was employed to collect the data for this study. A survey link was sent to physicians' professional organizations that forwarded it to their members and promoted the survey on social media. All registered GPs from Indonesian Medical Council living in Sumatera or Java were considerate eligible. If no response was received from a member, reminders were sent. To ensure the anonymity of the respondent and confidentiality of the data, the IP addresses of participants were not collected, and only the principal investigator had access to the survey account. The first page of the survey included information on the identity of the principal investigator, contact details, collaborating institutions, aims of the study, and its expected benefits. Before starting the survey, individuals provided their consent to participate. Potential participants were also informed that they could exit the survey at any point, but their responses that had already been recorded would still be uploaded to the database. At the end of the data collection period, the data were extracted from the survey host and imported into statistical software for analysis.

\section{Measures}

\section{Dependent variables}

The dependent variables in this study were knowledge and attitude among GPs in Indonesia towards pregnancyrelated problems of ZIKV infection. To assess knowledge, five questions were used. A correct response was given a score of one and an incorrect response was given a score of zero. The knowledge score was the sum of these five questions, ranging from 0 to 5 in which higher scores indicated greater knowledge. Four questions were used to assess attitude, and each question was rated on a 5-point Likert scale from 1 (strongly disagree) to 5 (strongly agree). To describe the distribution of responses to a question in the study population, participants who answered 4 or 5 were categorized as "agreeing" with the specific question. Subsequently, responses within the attitude domain using the 1 to 5 scale were added together giving an attitude score ranging from 4 to 20 in which higher scores indicated a more positive attitude. The responses to questions in which a higher score indicated a more negative attitude were flipped in order to preserve directionality across questions. See Additional file 2 for the detailed questions used to assess the knowledge and attitude domain.

\section{Independent variables}

We assessed four main groups of independent variables that could plausibly affect knowledge and attitude: sociodemographic status, workplace characteristics, medical professional development characteristics, and Zika-related experience. The sociodemographic characteristics included gender, age, education, and occupation. For statistical analysis purposes, the age of the respondents was divided into (a) 30 years or less, and (b) more than 30 years. Workplace characteristics included the specific department where the respondents worked, workplace type, and workplace location. To assess their medical professional development characteristics, respondents were asked about their medical experience (in year) and experience attending medical conference or training in the last five months. Zika-related experience was assessed whether respondents had contact with patient(s) presenting signs and symptoms of ZIKV infection.

\section{Statistical analysis}

All explanatory variables were divided into groups to give quantitative measures. The levels of knowledge and attitude were dichotomized into "good" and "poor" based on a $75 \%$ cut-off point of the total score within each domain (i.e., 4 out of 5, and 15 out of 20 for knowledge and attitude, respectively). Our studies have used a similar cut-off point of either $75 \%$ or $80 \%$ [51, 56, $60-$ 65]. The associations between the independent variables and the dependent variables (knowledge and attitude) were assessed using a two-step logistic regression. In the univariate logistic regression, all explanatory variables were analyzed, and variables with $P \leq 0.25$ in this step were entered into the multivariate analysis. The estimated crude odds ratio (OR) of the univariate analyses and the adjusted OR (aOR) of the multivariate analyses were interpreted in relation to a reference category (R).

The correlation and association between knowledge and attitude were assessed using Spearman's rank correlation $\left(\mathrm{r}_{\mathrm{s}}\right)$ and the Chi-square test, respectively. This correlation analysis was used due to the homogeneity of data variance. The confidence intervals for Spearman's 
rank correlation were calculated as previously described [66]. For all analyses, significance was assessed at $\alpha=0.05$. Statistical Package of Social Sciences 17.0 software (SPSS Inc., Chicago, IL, USA) was used to analyze the data.

\section{Results}

\section{Respondents' characteristics}

We received 850 responses during the survey period. Among these, 393 responses had to be excluded due to incomplete information, leaving a total of 457 (53.7\%) participants with complete responses. Approximately $60 \%$ of the participants were 30 years old or younger, and $66.3 \%$ of them had a medical practice experience of less than five years (Table 1). Approximately $10 \%$ of the respondents had an additional higher degree such as a master's or doctoral degree. The number of women was $16 \%$ higher than the number of men $(58.0 \%$ vs. $42.0 \%)$. The occupation of $12.3 \%$ of the respondents included an appointment both as a GP and university staff, and less than 10\% of them were specialist resident. A third of the participants were working in emergency units, and approximately the same number was working in community health centres (Puskesmas). The majority $(70.3 \%)$ of the GPs enrolled in this survey were working in a health centre located in the rural (district) or sub-urban (regency) areas, and about 30\% of them were working in the urban areas (provincial level). Although $66.1 \%$ of the participants had attended a provincial conference, $93.0 \%$ of them had not attended an international conference within the last five months. Approximately $8 \%$ of the surveyed GPs had had contact with a patient presenting signs and symptoms of ZIKV infection.

\section{Knowledge and associated determinants}

We rated 304 (66.5\%) respondents as having a good knowledge about pregnancy-related issues with ZIKV infection. Approximately $88.5 \%$ knew that ZIKV can be passed from a pregnant woman to the fetus, and 92.7\% knew that a baby could have congenital defects if infected during pregnancy. Interestingly, although $416(91.0 \%)$ correctly mentioned that microcephaly was a congenital condition associated with ZIKV infection, $65.8 \%$ of the respondents also answered that a ventricular septal defect was a complication associated with ZIKV infection. We assessed the association between knowledge and independent factors from four domains (sociodemographic status, workplace characteristics, professional development characteristics, and experience related to Zika disease). No factor was associated with knowledge (Table 1).

\section{Attitude and associated determinants}

Although the knowledge level of the respondents was relatively high, only $111(24.2 \%)$ of them had a positive attitude. Sixty percent of the respondents believed that women with ZIKV infection should undergo Caesarean section, or were not sure whether they should. Although more than $65 \%$ of the respondents believed that antibiotic treatment was not required for women with ZIKV infection, 107 (23.4\%) of them were still confused about this treatment option. In addition, almost $50 \%$ of the respondents believed that pregnant women with ZIKV infection should be treated with an antiviral drug, and $116(25.3 \%)$ were unsure whether antiviral medication was required.

Among the four domains of independent factors that were assessed, older age and contact experience with a patient presenting signs and symptoms of ZIKV infection were associated with a positive attitude in the univariate analysis (OR: $1.87,95 \%$ CI: $1.21-2.88, P=0.005$, and OR: 3.53 , 95\% CI: 1.76-7.05, $P<0.001$, respectively). The multivariate analysis revealed that only contact experience was significantly associated with attitude (OR: 3.14, 95\% CI: 1.49-6.58, $P=0.003$ ) (Table 2).

\section{Correlation and association between knowledge and attitude}

We found that there was a significant but weak positive correlation between knowledge and attitude towards pregnancy-related issues of ZIKV infection $(r=0.09$; 95\% CI: $0.02-0.18, P=0.037$ ). This indicates that attitude was increasingly positive with greater knowledge. To validate this result, further analysis was conducted using knowledge and attitude scores that had been classified as "good" and "poor" based on a cut-off point of $75 \%$. Our analysis indicated that there was no impact of knowledge on attitude using this classification system (OR: $1.41,95 \%$ CI: $0.88-2.25, P=0.154)$.

\section{Discussion}

General practitioners are frontline $\mathrm{HCWs}$ in Indonesia and other countries, and their ability to comprehensively react to cases of Zika disease in their communities is, in part, limited by the knowledge and attitudes that they hold. Studies on knowledge and attitude towards ZIKV infection among GPs are limited. Given the fact that HCWs have critical roles in the prevention and management of ZIKV infection, this study was conducted to fill this gap in the literature. We found that almost $40 \%$ of the participating GPs had a poor knowledge of pregnancy-related issues of ZIKV infection. For example, 73.9\% of respondents mentioned that ZIKV could be passed through breastfeeding. In fact, there are no reports to suggest that a ventricular septal defect was associated 


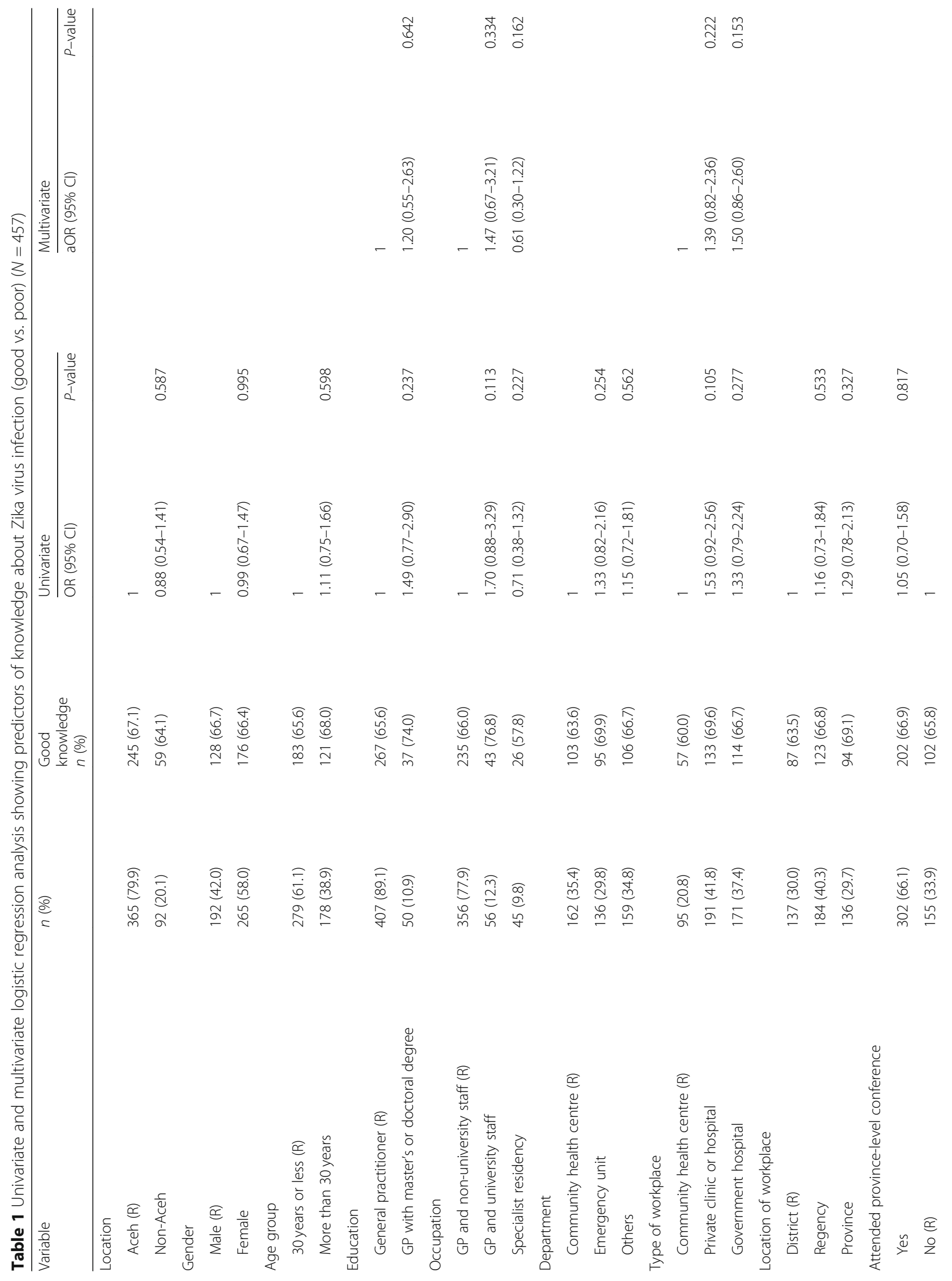




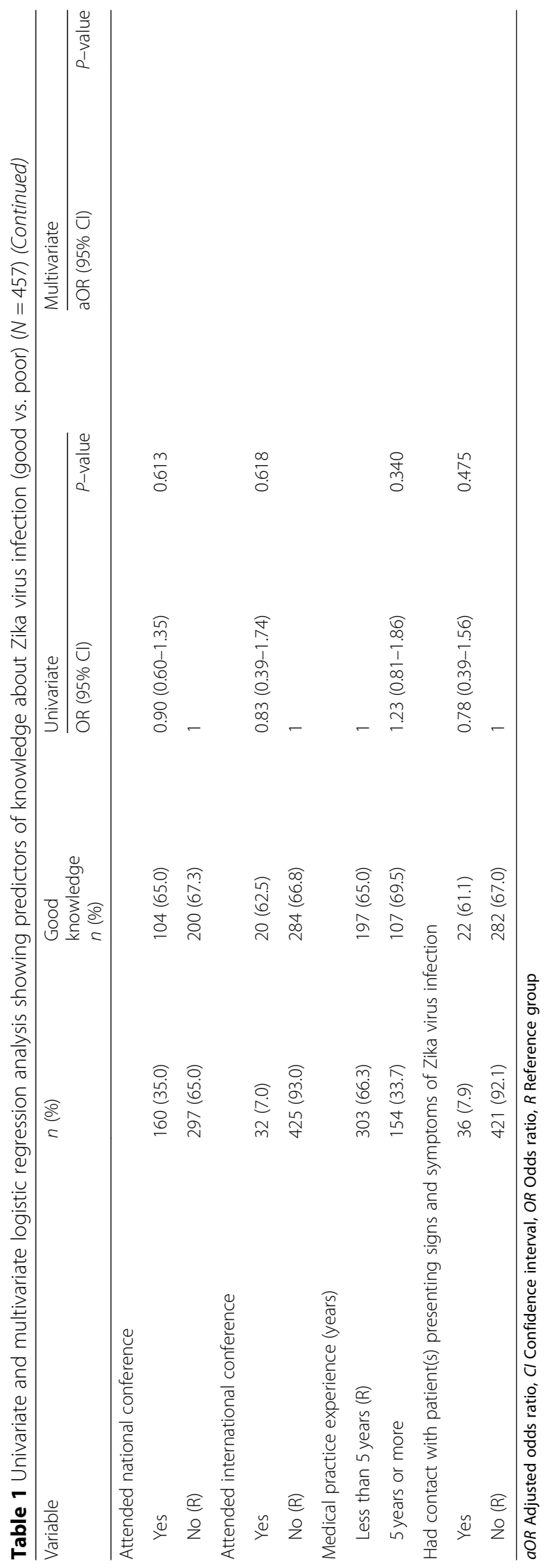




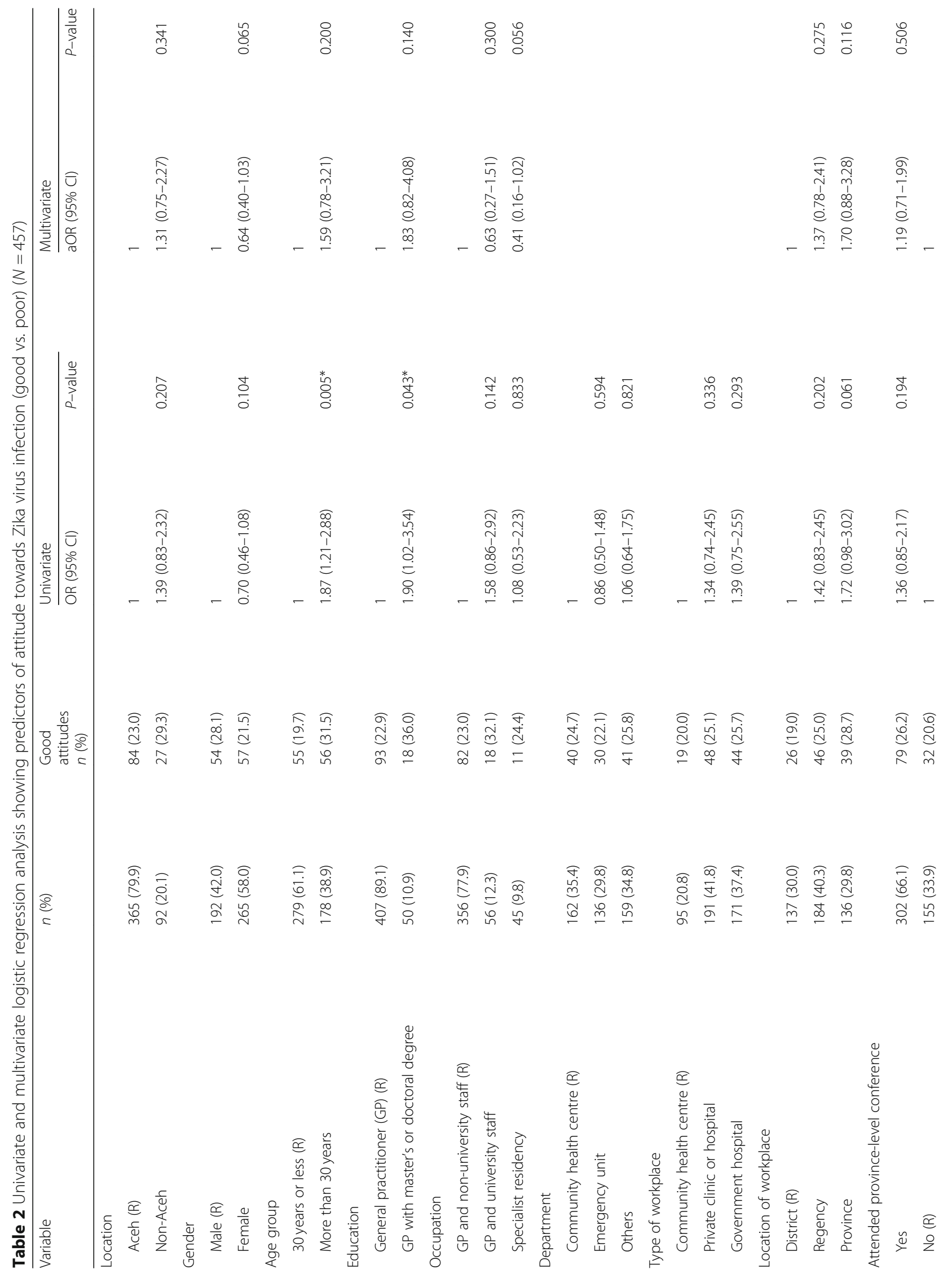




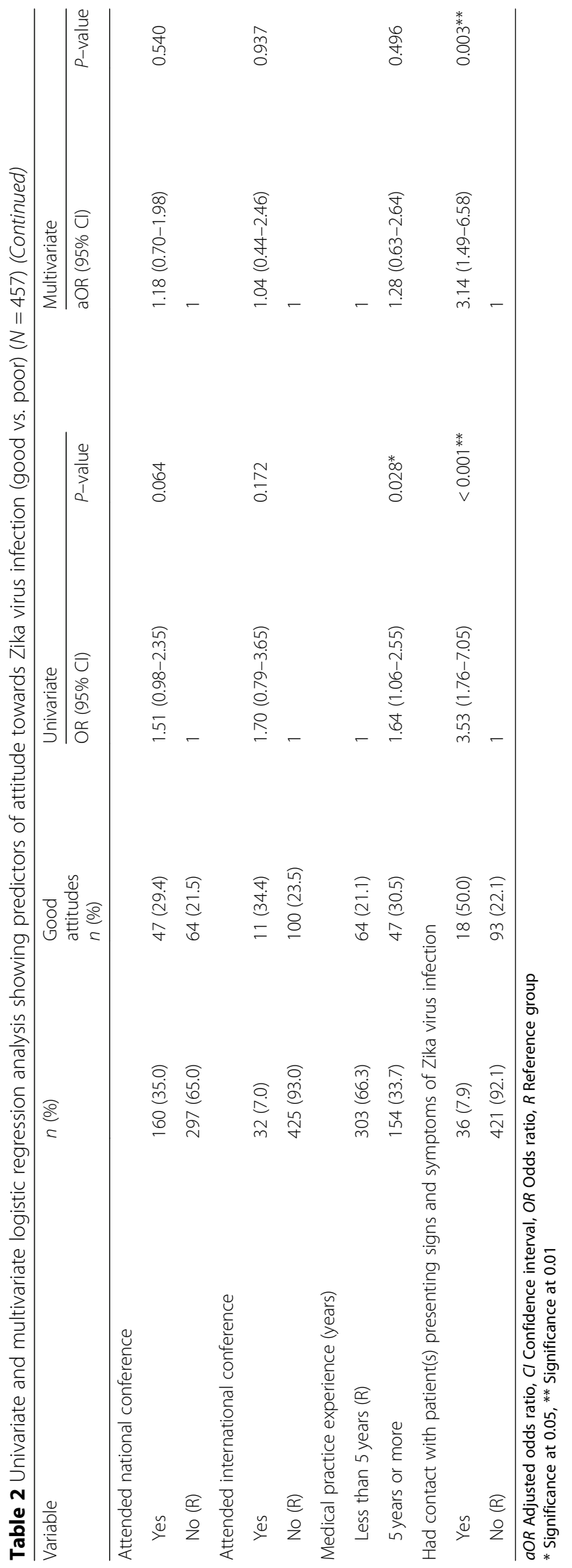


with ZIKV infection, and the U.S. CDC stated that there are no reports of infants getting ZIKV through breastfeeding, and mothers are encouraged to breastfeed even in areas with risk of Zika [67]. One of the plausible explanations of this finding is that ZIKV infection has not been a subject taught in Indonesia. For instance, Zika was not listed in the 2006 National General Practitioner Competence List of the Republic of Indonesia [68]. Therefore, while a few medical schools in Indonesia have incorporated the subject into their curriculum, this knowledge is not a mandatory subject for medical doctor graduates in Indonesia [69]. In addition, we found no independent factor that was significantly associated with knowledge among GPs. Previously, our study in Aceh province found that specialists had significantly lower knowledge compared to GPs, and some determinants relating to specialists were associated with lower knowledge [51]. For example, doctors whose workplace had access to medical journals (which was the case for most of the specialists) had lower knowledge compared to doctors whose workplace had restricted access to journals (e.g., in primary health service). In addition, doctors who worked in community health centres had greater knowledge compared to doctors who were working in private clinics or private hospitals and government hospitals, where most doctors were specialists. Therefore, it is not surprising that none of the independent variables were associated with knowledge in this survey because all of the respondents were GPs with a homogenous knowledge base. All of the respondents of this study received their medical education from the national curricula based on the 2006 National General Practitioner Competence List [68], where Zika was not listed as a compulsory disease.

We found that $66.3 \%$ of the participants had a medical practice experience of less than 5 years, and only $7.9 \%$ of the total participants stated that they had been contacted by a patient presenting signs and symptoms of ZIKV infection. These characteristics suggest that most of our participants could be considered to be at an intermediate level of expertise instead of an expert level [70]. Doctors at an intermediate level of expertise are better at recalling more signs and symptoms because they are able to focus on isolated signs and symptoms, and connect them to a pathophysiology mechanism [70]. In contrast, experts commonly use encapsulated knowledge or short-cut knowledge which is constructed from the memories of previous patients, which creates illness scripts. As a consequence, the expert may be inhibited in recalling signs and symptoms [70]. This could explain why most of our participants had relatively good knowledge about ZIKV infection compared to the specialist doctors in our previous survey [51]. Yet, the GPs could also be categorized as having incomprehensive knowledge about ZIKV infection since there were misperceptions about several aspects of the infection (i.e., that ZIKV could be transmitted via breastfeeding and that ventricular septal defect could be caused by the infection).

This incomprehensive knowledge, interestingly, was not adequate to improve GPs' attitude towards ZIKV infection management because attitude change requires more than merely cognitive or knowledge transformation but also relies on affective and behavioural dimensions of change [71]. Attitude is a summary evaluation of an object of thought that is constructed in a particular situation; it is context-dependent [71]. To improve GPs' attitude towards ZIKV infection, more exposure to cases of ZIKV infection is therefore required, to provide some experience enabling them to acquire diagnostic and management knowledge and to apply their knowledge in a practical setting [72]. The lack of exposure of real cases of ZIKV infection produces fewer opportunities for the GPs to apply their relatively good knowledge on ZIKV infection, and as a result the knowledge generates less of an impact on their attitudes. This might, in part, explain the lack of an association between knowledge and attitude among GPs.

This study revealed that GPs who had had contact with patient(s) presenting signs and symptoms of ZIKV infection were three times more likely to have a positive attitude. This finding could be explained by the experiential learning theory, in which learners will have better perception and cognition towards a disease if they are directly exposed to actual cases [73].

In general, our present study together with our previous survey [51] indicates that knowledge of ZIKV infection in HCWs in Indonesia is relatively low. Therefore, strategies for enhancing the capacity of HCWs (including GPs and other healthcare staffs) to respond to ZIKV infection may be needed. Scholars in the field of knowledge management have focused on knowledge seeking behavior of GPs at the global level. One study described a preference of GPs for local knowledge, for example, transfers from their own experiences or colleagues' experiences and communication with leaders in their institution, as a reaction to the overwhelming information overload from 400.000 medical articles published each year [74]. In addition, GPs preferred interactive sessions in workshops and conferences over didactic lectures to improve their performance in clinical decision making $[75,76]$. Therefore, efforts to increase GPs' knowledge on ZIKV infection should be supported by incorporating relevant information regarding ZIKV infection in continuing medical education (CME) programmes in collaboration with the Indonesian Medical Council which regulates future GPs' competence and certification. 
Online survey research has advantages which include time and cost benefits, however, this study is not without limitations. The results from this study, therefore, should be interpreted with caution. First, the incomplete response rate in this survey is high (46.3\%) if compared to our previous survey $[51,56]$. Second, there is potential for biased geographical selection of respondents because certain localities in Indonesia are less likely to have internet access than others. Third, we did not collect the exact location of the respondents making it not possible to create a map showing spatial heterogeneity. However, our study is still able to show the distribution of the respondents between rural (district) and urban (regency) areas. In addition, we also analyzed respondents based on type of workplace, which is one of the most important heterogeneity analysis in medical setting because it reflects facility characteristics. Finally, dishonesty can be an issue in the sense that some respondents may not have been fully truthful with their answers, or may have looked up the correct response to answers. To minimize this last issue, a clear introduction on the first page of the survey was provided asking participants to respond based on their current knowledge and beliefs without trying to find the correct answer from other resources.

\section{Conclusions}

This study reveals that the knowledge about pregnancyrelated problems with ZIKV infection is relatively high and homogenous among GPs across the most populous regions of Indonesia. However, GPs in Indonesia still have a poor attitude towards pregnancy-related problems of ZIKV infection, although contact experience with a patient presenting signs and symptoms of ZIKV infection was associated with a more positive attitude. Strategies for enhancing the capacity of GPs in Indonesia to respond to ZIKV infection are needed. Although the global emergency regarding ZIKV infection has been lifted, Indonesia is still at risk for ZIKV transmission, rendering medical education about ZIKV highly important and relevant for prevention and control efforts. One of the efforts with long-term effect will be to include the prevention and management of ZIKV infection in the National General Practitioner Competence List of Indonesia.

\section{Additional files}

Additional file 1: Completed of STROBE checklist of the study.

(PDF $478 \mathrm{~kb}$ )

Additional file 2: Detailed questions used to assess knowledge and attitude domain. (PDF $342 \mathrm{~kb}$ )

\section{Abbreviations}

aOR: Adjusted odds ratio; CDC: Centers for Disease Control and Prevention; CME: Continuing medical education; GP: General practitioners;
HCW: Healthcare worker; OR: Crude odds ratio; R: Reference category; $r_{s}$ : Spearman's rank correlation; SPSS: Statistical Package of Social Sciences; ZIKV: Zika virus

\section{Acknowledgments}

We would like to thank to physicians' professional organizations in Indonesia.

\section{Authors' contributions}

Study concept and design: HH. Data collection: HH, PSU, AMS, AA, AB, MRR, II1, NW, RM, II. Acquisition, analysis, or interpretation of data: HH, YR, PSU, SA, AMS, RI, ALW, AJR, MM, Al. Statistical analysis: HH, SA. Drafting of the manuscript: HH, PSU, RI. Critical revision of the manuscript for important intellectual content: HH, ALW, UK, DAG, AJR, MA, RM, MM, Al. All authors read and approved the final manuscript.

\section{Funding}

$\mathrm{HH}$ is received Australia Awards Scholarship (AAS) from the Department of Foreign Affairs and Trade, Australia, Scholarship for International Research Fees (SIRF) from The University of Western Australia and NHMRC Centre of Research Excellence in Emerging Infectious Diseases (CREID) Scholarship. RM, UK and DAG were supported by the Federal Ministry of Education and Research under the program "Nationales Forschungsnetz Zoonotische Infektionskrankheiten" (01KI1717). The funders had no role in study design, data collection and analysis, decision to publish, or preparation of the manuscript.

\section{Availability of data and materials}

The datasets used and/or analyzed during the current study are available from the corresponding author on reasonable request.

\section{Ethics approval and consent to participate}

The study was approved by the Human Research Ethics Committee of the School of Medicine, Universitas Syiah Kuala. This was an electronic survey. Potential participants were first shown an informed consent document and were instructed to click "Yes" if they agreed to the procedures. As per the protocol approved by the ethical review committee, individuals' electronic signatures were not collected in order to limit the amount of personally identifiable information held by the researchers. No direct incentive was given to participate in this survey.

\section{Consent for publication}

Not applicable.

\section{Competing interests}

The authors declare that they have no competing interests.

\section{Author details}

${ }^{1}$ Medical Research Unit, School of Medicine, Universitas Syiah Kuala, Banda Aceh, Indonesia. ${ }^{2}$ Tropical Disease Centre, School of Medicine, Universitas Syiah Kuala, Banda Aceh, Indonesia. ${ }^{3}$ Department of Microbiology, School of Medicine, Universitas Syiah Kuala, Banda Aceh, Indonesia. ${ }^{4}$ School of Biomedical Sciences, The University of Western Australia, Nedlands, Australia. ${ }^{5}$ Universiti Tunku Abdul Rahman, Kajang, Selangor, Malaysia. ${ }^{6}$ Department of Medical Education, Faculty of Medicine, Gadjah Mada University, Jogjakarta, Indonesia. ${ }^{7}$ Department of Statistics, Faculty of Mathematics and Natural Sciences, Universitas Syiah Kuala, Banda Aceh, Indonesia. ${ }^{8}$ Department of Microbiology, Faculty of Medicine and Health Sciences, Maulana Malik Ibrahim State Islamic University of Malang, Malang, Indonesia. 'Department of Family Medicine, School of Medicine, Universitas Syiah Kuala, Banda Aceh, Indonesia. ${ }^{10}$ Department of Microbiology, School of Medicine, Atma Jaya Catholic University of Indonesia, Jakarta, Indonesia. ${ }^{11}$ Medical Education Unit, School of Medicine, Universitas Syiah Kuala, Banda Aceh, Indonesia. ${ }^{12}$ Sydney School of Education and Social Work, Faculty of Arts and Social Sciences, The University of Sydney, Sydney, Australia. ${ }^{13}$ Department of Epidemiology, University of Michigan, Ann Arbor, MI, USA. ${ }^{14}$ Institute of Occupational Medicine, Social Medicine and Environmental Medicine, Goethe University, Frankfurt am Main, Germany. ${ }^{15}$ Public Health and Infection Research Incubator and Group, Faculty of Health Sciences, Universidad Tecnológica de Pereira, Pereira, Risaralda, Colombia. ${ }^{16}$ Research Group Medical and Diagnostic Images (GRIMEID), IPS Imágenes Diagnósticas S.A, Pereira, Risaralda, Colombia. ${ }^{17}$ Department of Obstetrics and Gynecology, School of 
Medicine, Universitas Syiah Kuala, Banda Aceh, Indonesia. ${ }^{18}$ Unit of Medical Entomology, Institute of Tropical Medicine, Antwerp, Belgium.

\section{Received: 9 June 2018 Accepted: 18 July 2019} Published online: 06 August 2019

\section{References}

1. Sabogal-Roman JA, Murillo-Garcia DR, Yepes-Echeverri MC, Restrepo-Mejia JD, Granados-Alvarez S, Paniz-Mondolfi AE, Villamil-Gomez WE, Zapata-Cerpa DC, Barreto-Rodriguez K, Rodriguez-Morales AJ. Healthcare students and workers' knowledge about transmission, epidemiology and symptoms of Zika fever in four cities of Colombia. Travel Med Infect Dis. 2016;14(1):52-4.

2. Lissauer D, Smit E, Kilby MD. Zika virus and pregnancy. BJOG. 2016;123(8):1258-63.

3. Suy A, Sulleiro E, Rodo C. Prolonged Zika virus viremia during pregnancy. NEJM. 2016;375(26):2609-11.

4. de Araujo TVB, Ximenes RAA, Miranda-Filho DB, Souza WV, Montarroyos UR, de Melo APL, Valongueiro S, de Albuquerque M, Braga C, Filho SPB, et al. Association between microcephaly, Zika virus infection, and other risk factors in Brazil: final report of a case-control study. Lancet Infect Dis. 2018;18(3):328-36

5. Cauchemez S, Besnard M, Bompard P, Dub T, Guillemette-Artur P, Eyrolle -Guignot D, Salje H, Van Kerkhove MD, Abadie V, Garel C, et al. Association between Zika virus and microcephaly in French Polynesia, 2013-15: a retrospective study. Lancet. 2016;387(10033):2125-32.

6. de Araujo TVB, Rodrigues LC, Ximenes RADA, Miranda-Filho DDB, Montarroyos UR, de Melo APL, Valongueiro S, de Albuquerque MDFPM, Souza W, Braga C, et al. Association between Zika virus infection and microcephaly in Brazil, January to may, 2016: preliminary report of a case -control study. Lancet Infect Dis. 2016;16(12):1356-63.

7. Vissoci JRN, Rocha TAH, Silva NCD, de Sousa Queiroz RC, Thomaz EBAF, Amaral PVM, Lein A, Branco MDRFC, Aquino J Junior, Rodrigues ZMR, et al. Zika virus infection and microcephaly: Evidence regarding geospatial associations. PLoS Negl Trop Dis. 2018;12(4):e0006392.

8. Schuler-Faccini L, Ribeiro EM, Feitosa IML, Horovitz DDG, Cavalcanti DP, Pessoa A, Doriqui MJR, Neri Jl, Neto JMD, Wanderley HYC, et al. Possible association between Zika virus infection and microcephaly - Brazil, 2015. MMWR Morb Mortal Wkly Rep. 2016;65(3):59-62.

9. de Oliveira WK, de Franca GVA, Carmo EH, Duncan BB, de Souza KR, Schmidt MI. Infection-related microcephaly after the 2015 and 2016 Zika virus outbreaks in Brazil: a surveillance-based analysis. Lancet. 2017; 390(10097):861-70.

10. Gulland A. Zika virus is a global public health emergency, declares WHO. BMJ. 2016:352

11. Moi ML, Nguyen TTT, Nguyen CT, Vu TBH, Tun MMN, Pham TD, Pham NT, Tran T, Morita K, Le TQM, et al. Zika virus infection and microcephaly in Vietnam. Lancet Infect Dis. 2017;17(8):805-6.

12. Wongsurawat $T$, Athipanyasilp $N$, Jenjaroenpun $P$, Jun SR, Kaewnapan B, Wassenaar TM, Leelahakorn N, Angkasekwinai N, Kantakamalakul W, Ussery DW et al. Case of microcephaly after congenital infection with Asian lineage Zika virus, Thailand. Emerg Infect Dis. 2018;24(9):1758-61.

13. Lim SK, Lim JK, Yoon IK. An Update on Zika Virus in Asia. Infect Chemother. 2017;49(2):91-100

14. Dick GWA, Kitchen SF, Haddow AJ. Zika Virus .1. Isolations and serological specificity. T Roy Soc Trop Med H. 1952:46(5):509-20.

15. Macnamara F. Zika virus: a report on three cases of human infection duringan epidemic of jaundice in Nigeria. T Roy Soc Trop Med $\mathrm{H}$. 1954;48:139-45.

16. Duffy MR, Chen TH, Hancock WT, Powers AM, Kool JL, Lanciotti RS, Pretrick M, Marfel M, Holzbauer S, Dubray C, et al. Zika virus outbreak on Yap Island, Federated States of Micronesia. N Engl J Med. 2009;360(24):2536-43.

17. Hennessey M, Fischer M, Staples JE. Zika virus spreads to new areas - region of the Americas, may 2015-January 2016. MMWR Morb Mortal Wkly Rep. 2016;65(3):55-8

18. WHO. Zika Situation Report. http://www.who.int/emergencies/zika-virus/ situation-report/10-march-2017/en/. Accessed 20 June 2019.

19. Messina JP, Kraemer MU, Brady OJ, Pigott DM, Shearer FM, Weiss DJ, Golding N, Ruktanonchai CW, Gething PW, Cohn E, et al. Mapping global environmental suitability for Zika virus. Elife. 2016;5:e15272.

20. Dyer O. Zika virus is set to spread through Asia, WHO says: BMJ. 2016; $355: 15577$.
21. Bogoch II, Brady OJ, Kraemer MU, German M, Creatore MI, Brent S, Watts AG, Hay SI, Kulkarni MA, Brownstein JS. Potential for Zika virus introduction and transmission in resource-limited countries in Africa and the Asia-Pacific region: a modelling study. Lancet Infect Dis. 2016;16(11):1237-45.

22. Dhimal M, Dahal S, Dhimal ML, Mishra SR, Karki KB, Aryal KK, Haque U, Kabir MI, Guin P, Butt AM, et al. Threats of Zika virus transmission for Asia and its Hindu-Kush Himalayan region. Infect Dis Poverty. 2018;7(1):40.

23. Siraj AS, Perkins TA. Assessing the population at risk of Zika virus in Asia - is the emergency really over? BMJ Glob Health. 2017;2(3):e000309

24. Olson J, Ksiazek T, Gubler D, Lubis S, Simanjuntak G, Lee V, Nalim S, Juslis K, See R. A survey for arboviral antibodies in sera of humans and animals in Lombok, Republic of Indonesia. Ann Trop Med Parasitol. 1983;77(2):131-7.

25. Olson J, Ksiazek T. Zika virus, a cause of fever in Central Java, Indonesia. Trans R Soc Trop Med Hyg. 1981;75(3):389-93.

26. Sasmono RT, Dhenni R, Yohan B, Pronyk P, Hadinegoro SR, Soepardi EJ, Ma'roef CN, Satari HI, Menzies H, Hawley WA, et al. Zika virus seropositivity in 1-4-year-old children, Indonesia, 2014. Emerg Infect Dis. 2018;24(9):1740-3.

27. Kwong JC, Druce JD, Leder K. Case report: Zika virus infection acquired during brief travel to Indonesia. Am J Trop Med Hyg. 2013;89(3):516-7.

28. Leung GH, Baird RW, Druce J, Anstey NM. Zika virus infection in Australia following a monkey bite in Indonesia. Southeast Asian J Trop Med Public Health. 2015;46(3):460-4

29. Perkasa A, Yudhaputri F, Haryanto S, Hayati RF, Ma'roef CN, Antonjaya U, Yohan B, Myint KSA, Ledermann JP, Rosenberg R. Isolation of Zika virus from febrile patient, Indonesia. Emerg Infect Dis. 2016;22(5):924-5.

30. Piltch-Loeb R, Kraemer J, Lin KW, Stoto MA. Public health surveillance for Zika virus: data interpretation and report validity. Am J Public Health. 2018;108(10):1358-62.

31. Gyurech D, Schilling J, Schmidt-Chanasit J, Cassinotti P, Kaeppeli F, Dobec M. False positive dengue NS1 antigen test in a traveller with an acute Zika virus infection imported into Switzerland. Swiss Med Wkly. 2016;146:w14296.

32. Garcia Serpa Osorio-de-Castro C, Silva Miranda E, Machado de Freitas C, Rochel de Camargo K Jr, Cranmer HH. The Zika virus outbreak in Brazil: knowledge gaps and challenges for risk reduction. Am J Public Health. 2017;107(6):960-5.

33. Cheema S, Maisonneuve P, Weber I, Fernandez-Luque L, Abraham A, Alrouh $\mathrm{H}$, Sheikh J, Lowenfels AB, Mamtani R. Knowledge and perceptions about Zika virus in a Middle East country. BMC Infect Dis. 2017;17(1):524.

34. Huang $Y, X u$ S, Wang L, Zhao Y, Liu H, Yao D, Xu Y, Lv Q, Hao G, Wu Q. Knowledge, attitudes, and practices regarding Zika: paper- and internetbased survey in Zhejiang, China. JMIR Public Health Surveill. 2017;3(4):e81.

35. Khan MU, Ahmad A, Arief M, Saleem F, Hassali MA, Bhagavathula AS. Public knowledge and attitudes towards Zika virus and its prevention in Malaysia. Value Health. 2016;19(7):A423.

36. Khawar. Knowledge and risk perceptions of Zika virus among attendees of the 2016 summer olympic games. Acad Emerg Med. 2017;24:S272.

37. Ramírez G, Álvarez L. Knowledge, attitudes and practices regarding dengue, chikungunya, and zika and their vector Aedes aegypti in Villavicencio, Colombia. Open Public Health J. 2017;10:80-9.

38. Curry CL, Tse C, Billero V, Hellerstein L, Messore M, Fein L. Knowledge and perceptions of Zika virus among reproductive-aged women after public announcement of local mosquito-borne transmission. J Obstet Gynaecol Res. 2018:44:505-8.

39. Raman A, Dubaut J, Burks H, Quaas A. Knowledge, attitudes and practices regarding zikavirus in patients presenting for infertility treatment and health care professionals. Fertil Steril. 2017;108(3 Supplement 1):e328-9.

40. Berenson AB, Trinh HN, Hirth JM, Guo F, Fuchs EL, Weaver SC. Knowledge and prevention practices among U.S. pregnant immigrants from Zika virus outbreak areas. Am J Trop Med Hyg. 2017;97(1):155-62.

41. Mouchtouri VA, Papagiannis D, Katsioulis A, Rachiotis G, Dafopoulos K, Hadjichristodoulou C. Knowledge, attitudes, and practices about the prevention of mosquito bites and Zika virus disease in pregnant women in Greece. Int J Environm Res Publ Health. 2017;14(4):E367.

42. Villers M, Edwards J, Heine R, Small M. Knowledge of Zika virus and patient prenatal screening and testing preferences. Am J Obstet Gynecol. 2017; 216(1 Supplement 1):S206

43. Whittemore K, Tate A, Illescas A, Saffa A, Collins A, Varma JK, Vora NM. Zika virus knowledge among pregnant women who were in areas with active transmission. Emerg Infect Dis. 2017;23(1):164-6.

44. Moore KJ, Qualls W, Brennan V, Yang X, Caban-Martinez AJ. Mosquito control practices and Zika knowledge among outdoor construction workers in Miami-Dade County, Florida. J Occup Environ Med. 2017;59(3):e17-9. 
45. Betancourt-Trejos ML, Narvaez-Maldonado CF, Ortiz-Erazo WF, Arias-Guzman JS, Gil-Restrepo AF, Sanchez-Rueda MA, Munoz-Calle NJ, Maya-Betancourth $J G$, Rodriguez-Morales AJ. Healthcare students and workers' knowledge about Zika and its association with microcephaly in two cities of Colombia. Travel Med Infect Dis. 2016;14(3):283-5.

46. Bhat S, Gabbur N. Zika knowledge among pregnant women in an inner-city urban hospital. Obstet Gynecol. 2017;129:135S.

47. Gokce A, Ozer A, Bentli R, Tekedereli I. Knowledge level of medical students about Zika virus disease in Malatya, an eastern city of Turkey. Eur J Pub Health. 2016;26:452.

48. Ibrahim NK, Moshref RH, Moshref LH, Walid JB, Alsati HS. Knowledge and attitudes towards Zika virus among medical students in King Abdulaziz University, Jeddah, Saudi Arabia. J Infect Public Health. 2017;11:18-23.

49. Gupta N, Randhawa RK, Thakar S, Bansal M, Gupta P, Arora V. Knowledge regarding Zika virus infection among dental practitioners of tricity area (Chandigarh, Panchkula and Mohali), India. Niger Postgrad Med J. 2016;23(1):33-7.

50. Yung CF, Tam CC, Rajadurai VS, Chan JK, Low MS, Ng YH, Thoon KC, Tan LK. Rapid assessment Zika virus knowledge among clinical specialists in Singapore: a cross-sectional survey. PLoS Curr. 2017;9:ecurrents.outbreaks. 44b19196298e01f3a6dcd4c09f235fa8.

51. Harapan H, Aletta A, Anwar S, Setiawan A, Maulana R, Wahyuniati N, Ramadana R, Haryanto S, Rodríguez-Moralesh A, Jamil K. Healthcare workers' knowledge towards Zika virus infection in Indonesia: a survey in Aceh. Asian Pac J Trop Med. 2017;10(2):189-94.

52. Iqbal M, Lokanayagi S, Rahul R, Sunil K, Tahir M. Knowledge, attitude and perception of Zika virus among healthcare students of medicine, pharmacy and dentistry of Aimst University. Value Health. 2016;19(7):A484.

53. Painter JE, Plaster AN, Tjersland DH, Jacobsen KH. Zika virus knowledge, attitudes, and vaccine interest among university students. Vaccine. 2017; 35(6):960-5.

54. Wong LP, Alias H, Hassan J, AbuBakar S. Attitudes towards Zika screening and vaccination acceptability among pregnant women in Malaysia. Vaccine. 2017;35(43):5912-7.

55. Dickson DA, Mankee-Sookram S, Jess N, Minto-Bain CL, Ramsewak S. Knowledge, attitudes and practices of patients of a fertility clinic in a Zika -endemic Caribbean country. Fertil Steril. 2017;108(3):E327-8.

56. Harapan H, Alleta A, Anwar S, Setiawan AM, Maulana R, Wahyuniati N, Ramadana MR, Ikram I, Haryanto S, Jamil KF, et al. Attitudes towards Zika virus infection among medical doctors in Aceh province, Indonesia. J Infect Public Health. 2018;11(1):99-104.

57. Indonesian Medical Council. Standar Kompetensi Dokter Indonesia. Jakarta: Indonesian Medical Council; 2012.

58. Meaney-Delman D, Rasmussen SA, Staples JE, Oduyebo T, Ellington $\mathrm{SR}$, Petersen EE, Fischer $\mathrm{M}$, Jamieson DJ. Zika virus and pregnancy: what obstetric health care providers need to know. Obstet Gynecol. 2016;127(4):642-8.

59. Noah N. The STROBE initiative: STrengthening the reporting of OBservational studies in epidemiology (STROBE). Epidemiol Infect. 2008;136(7):865.

60. Harapan H, Anwar S, Bustaman A, Radiansyah A, Angraini P, Fasli R, Salwiyadi S, Bastian RA, Oktiviyari A, Akmal I, et al. Modifiable determinants of attitude towards dengue vaccination among healthy inhabitants of Aceh, Indonesia: findings from a community-based survey. Asian Pac J Trop Med. 2016;9(11):1092-8.

61. Harapan H, Anwar S, Bustamam A, Radiansyah A, Angraini P, Fasli R, Salwiyadi S, Bastian RA, Oktiviyari A, Akmal l, et al. Willingness to pay for a dengue vaccine and its associated determinants in Indonesia: a community -based, cross-sectional survey in Aceh. Acta Trop. 2017;166:249-56.

62. Harapan H, Anwar S, Setiawan AM, Sasmono RT, Study AD. Dengue vaccine acceptance and associated factors in Indonesia: a community-based cross -sectional survey in Aceh. Vaccine. 2016:34(32):3670-5.

63. Harapan H, Rajamoorthy Y, Anwar S, Bustamam A, Radiansyah A, Angraini P, Fasli R, Salwiyadi S, Bastian RA, Oktiviyari A, et al. Knowledge, attitude, and practice regarding dengue virus infection among inhabitants of Aceh, Indonesia: a cross-sectional study. BMC Infect Dis. 2018;18:96.

64. Harapan H, Mudatsir M, Yufika A, Nawawi Y, Wahyuniati N, Anwar S, Yusri F, Haryanti N, Wijayanti NP, Rizal R, et al. Community acceptance and willingness-to-pay for a hypothetical Zika vaccine: A cross-sectional study in Indonesia. Vaccine. 2019;37(11):1398-6

65. Harapan H, Mudatsir M, Yufika A, Nawawi Y, Wahyuniati N, Anwar S, Yusri F, Haryanti N, Wijayanti NP, Rizal R. Willingness to participate and associated factors in a Zika vaccine trial in Indonesia: a cross-sectional study. Viruses. 2018;10(11):E648.

66. Bonett DG, Wright TA. Sample size requirements for estimating Pearson, Kendall and Spearman correlations. Psychometrika. 2000;65(1):23-8.

67. CDC. Zika virus. https://www.cdc.gov/zika/prevention/transmission-methods. html. Accessed 1 June 2018

68. Indonesian Medical Council. Standar Kompetensi Dokter Indonesia. Jakarta: Indonesian Medical Council; 2006.

69. Harapan H, Mudatsir M, Indah R, Utomo P, Anwar A, Wahyuniati N, Maulana R, Ichsan I, Aletta A, Ikram I, et al. Knowledge towards Zika among medical students, interns and general practitioners in Indonesia: a cross-sectional study in Aceh. Clin Epidemiol Glob Health. 2019; https://doi.org/10.1016/j. cegh.2018.12.006

70. Schmidt HG, Rikers RMJP. How expertise develops in medicine: knowledge encapsulation and illness script formation. Med Educ. 2007:41(12):1133-9.

71. Vogel T, Wanke M. Attitudes and attitude change 2 nd edition edn. New York: Routledge; 2016

72. Monajemi A, Rikers RMJP, Schmidt HG. Clinical case processing: a diagnostic versus a management focus. Med Educ. 2007;41(12):1166-72.

73. Yardley S, Teunissen PW, Dornan T. Experiential learning: AMEE Guide No. 63. Med Teach. 2012;34(2):E102

74. Nicolini D, Powell J, Conville P, Martinez-Solano L. Managing knowledge in the healthcare sector. A review. Int J Management Rev. 2008;10(3):245-63.

75. Davis D, O'Brien MAT, Freemantle N, Wolf FM, Mazmanian P, Taylor-Vaisey A Impact of formal continuing medical education - do conferences, workshops, rounds, and other traditional continuing education activities change physician behavior or health care outcomes? J Amer Med Assoc. 1999;282(9):867-74.

76. Cervero RM, Gaines JK. The impact of CME on physician performance and patient health outcomes: an updated synthesis of systematic reviews. J Contin Educ Health Prof. 2015:35(2):131-8.

\section{Publisher's Note}

Springer Nature remains neutral with regard to jurisdictional claims in published maps and institutional affiliations.
Ready to submit your research? Choose BMC and benefit from:

- fast, convenient online submission

- thorough peer review by experienced researchers in your field

- rapid publication on acceptance

- support for research data, including large and complex data types

- gold Open Access which fosters wider collaboration and increased citations

- maximum visibility for your research: over $100 \mathrm{M}$ website views per year

At $\mathrm{BMC}$, research is always in progress.

Learn more biomedcentral.com/submissions 